\title{
Botanical oils as eco-friendly alternatives for controlling the rice weevil Sitophilus oryzae
}

\author{
Saad, A. S. A., Elsayed H. M. Tayeb and Houria L. Metraw ${ }^{1}$
}

\begin{abstract}
The rice weevil Sitophilus oryzae is a major stored grain pest infesting many grains in storage mainly wheat, rice and maize. Toxic effects of certain extracted botanical essential oils (EOs) were evaluated against the adults of Sitophilus oryzae (Linnaeus) (Coleoptera: Curculionidae). Bioassays were carried out by fumigation and guide tables were presented to show the effective range of concentrations of each of the evaluated essential oils and their corresponding mean number of responded insects. The essential oil of fennel (seeds) (Foeniculum vulgare) did not show any toxic effect up to the concentration of $\mathbf{3 0 0}$ $\mu \mathrm{l} / 370 \mathrm{ml}$ air and Common Sage (Marmaria leaves) (Salvia officinalis) up to $250 \mu \mathrm{l} / 370 \mathrm{ml}$ air during the first $48 \mathrm{hrs}$ then they showed a very weak effect. The essential oil of spearmint leaves (Mentha spicata $\mathbf{L}$.) was the utmost toxic and had a lowest $\mathrm{LC}_{50 \text { s }}$ calculated by $4.43,3.88$ and 3.27 $\mu \mathrm{l} / 370 \mathrm{ml}$ air after different exposure periods of 24,48 and $72 \mathrm{hrs}$, respectively, followed by the essential oil of clove (Syzygium aromaticum) $(382.62,79.95$ and $9.23 \mu \mathrm{l} / 370 \mathrm{ml}$ air, in respect). In this concern, clove showed its higher toxicity after $72 \mathrm{hrs}$. The mortality of the exposed adults to EOs increased with the increase of concentrations and time of exposure to each one. The calculated values of toxicity index showed that the essential oil of mint was the most toxic EO $(100 \%)$ followed by clove $(35.43 \%)$. Moreover, log (dose)/N.E.D. (response) (Ld-p) regression lines for certain bio assayed botanical essential oils against $S$. oryzae were also illustrated. Therefore, it could be recommended that the essential oils of spearmint leaves and clove buds could be used to control the rice weevil, $S$. oryzae.
\end{abstract}

Keywords: Botanical oils; Sitophilus oryzae; Guide tables; $\mathrm{LC}_{50}$; Toxicity index; Ld-p lines

\section{INTRODUCTION}

Stored grains are subject to loss due to several causes, including physical, sanitary and nutritional degradation, from their maturation to the consumption. Grain loss may be caused by fungi, insect-pests and the inadequate handling from harvest to storage and all these factors can result in important financial losses (Lazzari and Lazzari, 2002). Loss may reach $10 \%$ of the total product each year, which translates to $10,000,000$ tons of grain lost per year (Smiderle, 2007). Among the stored grain insect-pests, the rice weevil Sitophilus oryzae (Linnaeus) (Coleoptera: Curculionidae), is considered to be the most important insect-pest of stored rice causing quantitative and qualitative losses (Sartori et al., 1990). This species is found throughout warm, tropical regions of the world and it may infest grains in the field prior to storage (Pacheco and Paula, 1995). In warmer regions, natural aeration is not sufficient to control infestations, requiring the application of chemical control (Moreira, 1993). However, the indiscriminate application of synthetic products (insecticides) had led to various problems including toxic residual effects, environmental pollution, and development of resistance in insects (Isman, 2006). The use of a mixture of insecticides also favors the development of resistant strains which then makes subsequent pest management difficult (Pereira $e t$ al., 1997).

The most effective and fast method to suppress stored grain pests is fumigation. Phosphine is the most used fumigant, but the incorrect use of phosphine has selected resistant pest populations (Calil, 1995). Methyl bromide, a widely used fumigant for insect pest control in stored products is not being used anymore because it has been reported to cause ozone depletion (Lee et al., 2001a). Therefore, there is an urgent need to develop safe, convenient and low-cost alternatives. Considerable efforts have been focused on the use of plant-derived materials including essential oils as bioinsecticides. Essential oils have demonstrated toxic effects against stored-product insects (Rajendran and Sriranjini, 2008). Essential oils and their components are gaining increasing interest because of their relatively safe use and potential for multi-purpose functional use (Feng and Zheng, 2007). These compounds are typically lipophylic, with potential for toxic interference in basic biochemical processes with physiological and behavioral consequences for the insects (Prates and Santos, 2002). Therefore, botanical insecticides may offer an alternative solution for pest control. Botanical essential oils and their constituents have been shown to possess potential for development as new fumigants and they may have advantages over conventional fumigants in terms of low mammalian toxicity and low environmental impact (Franz et al., 2011; Yazdgerdian et al., 2015). Such products of higher plant origin may be exploited as eco-chemical and biorational approach in integrated plant protection programs (Dubey et al., 2010).

\footnotetext{
${ }^{1}$ Plant Protection Dept., Faculty of Agriculture (Saba Basha), Alex. Univ., Egypt

Received December 06,2017, Accepted December 30, 2017
} 
It was acknowledged that various plant oils or extracts can exert toxic activity against some insect species. Essential oil of thyme, Thymus serpyllum (rich in thymol and carvacrol) was very effective when treated as fumigants against the bean weevil Acanthoscelides obtectus (Bruchidae) (Regnault-Roger et al., 1993). Mint, Mentha sp. (Labiatae) produces an essential oil rich in menthone (14-32\%) and menthol (30-50\%) (Cardoso et al., 2001). Menthol has wide application in the food and pharmaceutical industry; also exhibited insecticidal activity (Agarwal et al., 2001). Fennel extracts was reported to have insecticidal activity against different mites and insects (MimicaDukić et al., 2003 and Lee et al., 2006).

The objective of the present investigation was adopted to test the insecticidal properties of the extracted botanical essential oils of spearmint, bitter orange, lemon, the Brazilian pepper, thyme, sweet basil, fennel, clove, eucalyptus and sweet sage(Marmaria) as eco-friendly fumigants to be used for controlling the rice weevil, S. oryzae.

Table 1. The evaluated essential oils, the used plant parts and their major constituents

\begin{tabular}{|c|c|c|c|c|}
\hline \multicolumn{3}{|c|}{ Essential Oil } & \multirow[b]{2}{*}{$\begin{array}{l}\text { The used } \\
\text { part }\end{array}$} & \multirow{2}{*}{$\begin{array}{l}\text { Major constituents } \\
\text { of the essential oil }\end{array}$} \\
\hline Scientific Name & $\begin{array}{c}\text { Common } \\
\text { Name } \\
\end{array}$ & Family Name & & \\
\hline Citrus aurantium L. & Bitter Orange & Rutaceae & Peel & $\begin{array}{c}\text { Limonene }(89.8 \%-94.12) \\
\mathbf{1 \& 2}^{*}\end{array}$ \\
\hline Citrus limon $\mathrm{L}$. & Lemon & Rutaceae & Peel & Limonene $(93.5 \%)^{3}$ \\
\hline Ocimum basilicum L. & Sweet Basil & Lamiaceae & Leaves & $\begin{array}{c}\text { Eugenol }(75.1 \%)^{4} \\
\text { Linalool }(95 \%)^{5}\end{array}$ \\
\hline Schinus molle L. & $\begin{array}{l}\text { Brazilian } \\
\text { Pepper }\end{array}$ & Anacardiaceae & Leaves & $\begin{array}{c}\alpha \text {-Phellandrene }(20.6 \%), \beta \text { - } \\
\text { Phellandrene }(10.8 \%) \text { and } \alpha \text { - } \\
\text { Pinene }(8.7 \%)^{6}\end{array}$ \\
\hline Thymus vulgaris L. & Thyme & Lamiaceae & Leaves & $\begin{array}{c}1,8 \text { cineole }(34.69-40.67) \text { and } \\
\text { Linalool }(8.99-11.75)^{7}\end{array}$ \\
\hline Foeniculum vulgare Mill & Fennel & Apiaceae & Seeds & $\begin{array}{c}\text { Estragole } \\
(34 \text { to } 89 \%)^{8}\end{array}$ \\
\hline $\begin{array}{l}\text { Syzygium aromaticum } \\
\text { (Linn.) (Merrill. \& } \\
\text { Perry.) }\end{array}$ & Clove & Myrtaceae & Buds & $\begin{array}{c}\text { Eugenol }(71.56 \%) \text { and } \\
\text { eugenol acetate } \\
(8.99 \%)^{9}\end{array}$ \\
\hline $\begin{array}{c}\text { Cinnamomum camphora } \\
\text { Nees \& Eberm }\end{array}$ & Eucalyptus & Myrtaceae & Leaves & Camphor $(68.03 \%)^{\mathbf{1 0}}$ \\
\hline Salvia officinalis L. & $\begin{array}{l}\text { Common Sage } \\
\text { (Marmaria) }\end{array}$ & Lamiaceae & Leaves & $\begin{array}{c}\alpha \text {-Thujone }(40.90 \%) \text { and } \\
\text { camphor } \\
(26.12 \%)^{11}\end{array}$ \\
\hline Mentha spicata L. & Spearmint & Lamiaceae & Leaves & $\begin{array}{c}\text { Carvone }(40.8 \% \pm 1.23 \%) \\
\text { and limonene }(20.8 \% \pm \\
1.12 \%)^{\mathbf{1 2}}\end{array}$ \\
\hline
\end{tabular}

*1(Camara et al., 2015), 2(Bendaha et al., 2016), 3(Verzera et al., 2004), 4(Joshi, 2013), 5(Dambolena et al., 2010), 6(Abrha and Unnithan, 2014), 7(Cases et al., 2009), 8(He and Huang, 2011), 9(Nassar et al., 2007), 10(Frizzo et al., 2000), 11(Porte et al., 2013) and 12 (Snoussi et al., 2015). 


\section{The tested insect}

A susceptible laboratory strain of the rice weevil, Sitophilus oryzae, was obtained from a stock culture maintained at the laboratories of Plant Protection Dept., Faculty of Agric. (Saba Basha), Alex. Univ., Egypt. The adults of 2-3 weeks old were used for bioassay tests.

\section{Bioassay}

A Whatman (\#1) filter paper was treated with different concentrations of pure essential oil (a range of $1-300 \mu \mathrm{l} / 370 \mathrm{ml}$ air $)$. A piece of filter paper $(2 \times 2 \mathrm{~cm}$ for the concentrations of $1-100$ and $4 \times 4 \mathrm{~cm}$ for the other ones of $150-300 \mu 1 / 370 \mathrm{ml}$ air) was fixed in the center of the inner surface of a plastic lid of a $500 \mathrm{ml}$ glass jar. Each replicate (glass jar) implied 20 weevils. Mortality was assessed after 24, 48 and $72 \mathrm{hrs}$ while the glass jar was still closed. There were three replicates of $20 \mathrm{~S}$. oryzae for each concentration and the untreated check (control). Mortality of treatments was adjusted according to Abbott (1925) formula if a proportion of insect control died during the experiment.

\section{Data analysis}

Probit analysis was used to calculate $\mathrm{LC}_{50}$ (concentration causing 50\% mortality) compared with the control, $\mathrm{Lc}_{90}$ values and their fiducial limits (confidence intervals) for each evaluated essential oil that give a reasonable relation between dose and mortality (response) that could be used easily for probit analysis (Finney, 1971). Toxicity Index (\%) (based on $\mathrm{LC}_{50}$ after $72 \mathrm{hrs}$ ) was calculated according to Sun (1950). Toxicity Index $=$ Lc50 of the most toxic oil /Lc50 of the other compared oil. Meanwhile, the Ld-p lines of these essential oils were plotted.

\section{RESULTS AND DISCUSSION}

Mortality of $S$. oryzae varied from 10 to $100 \%$ after 24, 48 and $72 \mathrm{hrs}$ exposure to each of the bioassayed botanical essential oil (EOs) evaluated by the fumigation technique which was taken into consideration after testing a wide range of these EOs. The obtained results elucidated that the efficiency of the oils was directly related to concentration and response. The guide Tables: 2, 3 and 4 represent the detected effective range of the evaluated EOs concentrations, the mean number of dead insects ( $S$. oryzae adults) and mortality percentages after the different adopted periods of exposure [24 (Table 2), 48 (Table 3) and 72 hrs (Table4), respectively).

Such guide tables would be of great importance for the research workers since they will facilitate the selection of the concentrations that can be tested against the target insect.
Generally, it could be noticed that two essential oils showed little bioactivity (sweet basil and thyme), six oils caused significant adult mortality and two had none (fennel and common sage). Thyme was found to have a weakened delayed effect and was only efficient and more toxic after $72 \mathrm{hrs}$ of exposure but it was still the least effective oil.

The toxic effects of the essential oils are depending on both of the mode of action and the target pest (Liu et $a l ., 2006)$, besides, the species of the botanical material and its freshness.

Six EOs were found to be active as fumigants against $S$. oryzae exhibiting higher mortality at the initial evaluated concentrations and at the end of the exposure periods (after $72 \mathrm{hrs}$ ) as shown in Table 4. These oils showed a concentration - mortality relationship and therefore, $\mathrm{LC}_{50}$ values can be calculated and Ld-p lines can also be drawn. The essential oil of fennel (seeds) did not show any toxic effect up to the concentration of $300 \mu 1 / 370 \mathrm{ml}$ air and Common Sage (Marmaria leaves) up to $250 \mu \mathrm{l} / 370 \mathrm{ml}$ air). Nevertheless, extracts of fennel were found to be toxic against Culex pipiens larvae, and terpineol and 1,8-cineole were the most effective components against Anopheles dirus and Aedes aegypti, as shown by Kim and Ahn (2001), Traboulsi et al. (2005) and Lee et al. (2006) who suggested that fennel could be used as an alternative of synthetic insecticides.

Meanwhile, the essential oil of $O$. basilicum exhibited weak fumigant toxicity against $S$. oryzae adults. The essential oil of $O$. basilicum might be required in higher concentrations than those of the other tested EOs to kill stored- grain insects. The essential oil of spearmint leaves (Mentha spicata L.) was found to have the greatest toxicity and lower $\mathrm{LC}_{50 \mathrm{~s}}\left(\mathrm{LC}_{50}=12.32\right.$, 9.77 and $7.79 \mu \mathrm{l} / 370 \mathrm{ml}$ air) after different periods of exposure (24, 48 and $72 \mathrm{hrs,} \mathrm{respectively),} \mathrm{followed} \mathrm{by}$ the essential oil of clove $(382.62,79.95$ and $9.23 \mu 1 / 370$ $\mathrm{ml}$ air, in respect) (Table 5). It could be also noticed that clove showed its higher toxicity after $72 \mathrm{hrs}$. The essential oil of bitter orange peel was more toxic than that that of lemon against $S$. oryzae $\left(\mathrm{LC}_{50}\right.$ values $=$ 39.76 and $115.76 \mu \mathrm{l} / 370 \mathrm{ml}$ air, respectively).

The mortality of exposed adults to EOs increased with the increase of concentration and time of exposure.

Therefore, based on the deduced $\mathrm{LC}_{50}$ values of the tested oils, extracted essential oils of spearmint (Mentha spicata L.) and clove buds were the most active fumigants against the rice weevil Sitophilus oryzae, presenting safer alternatives to conventional insecticides. 


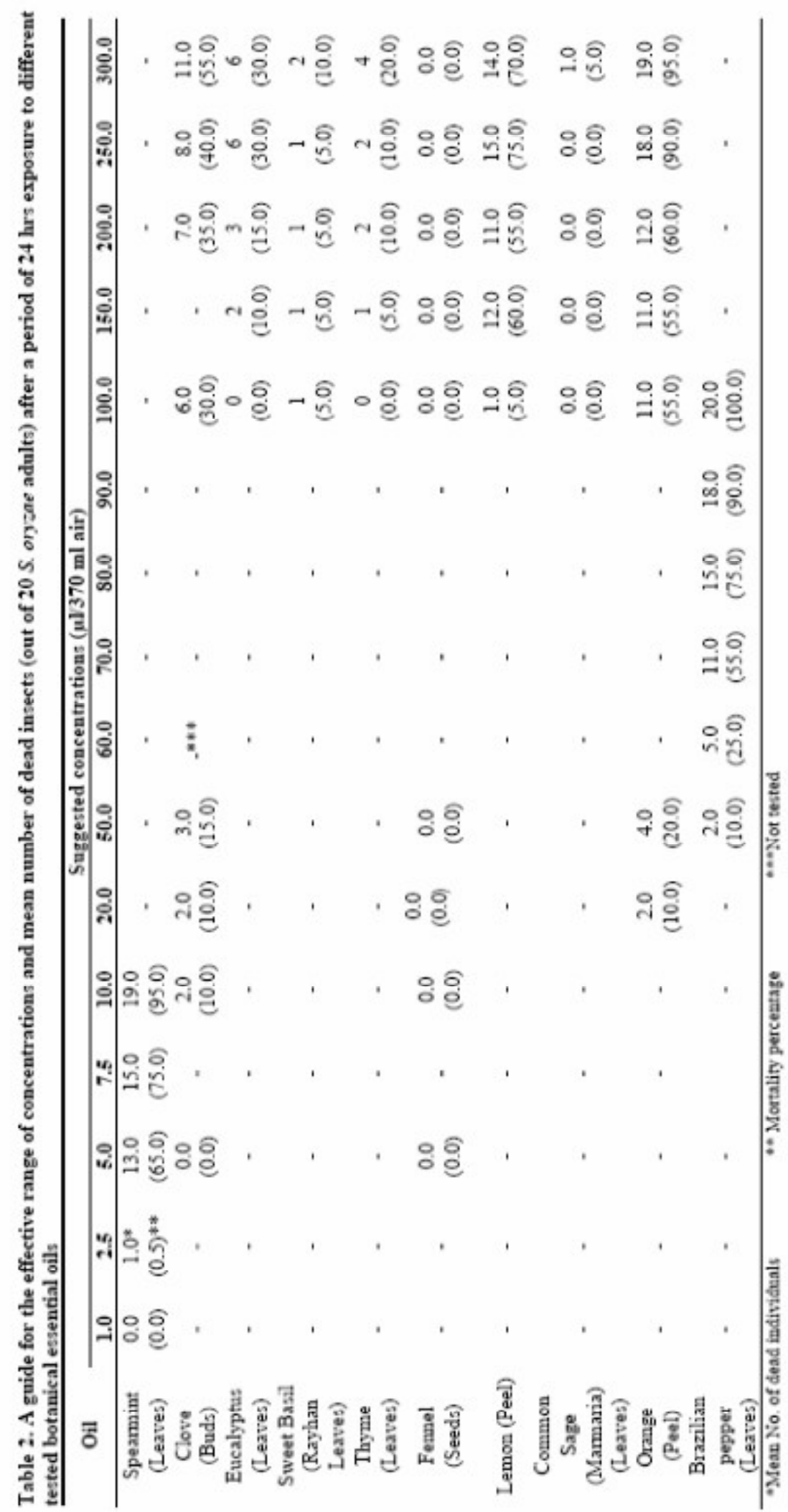




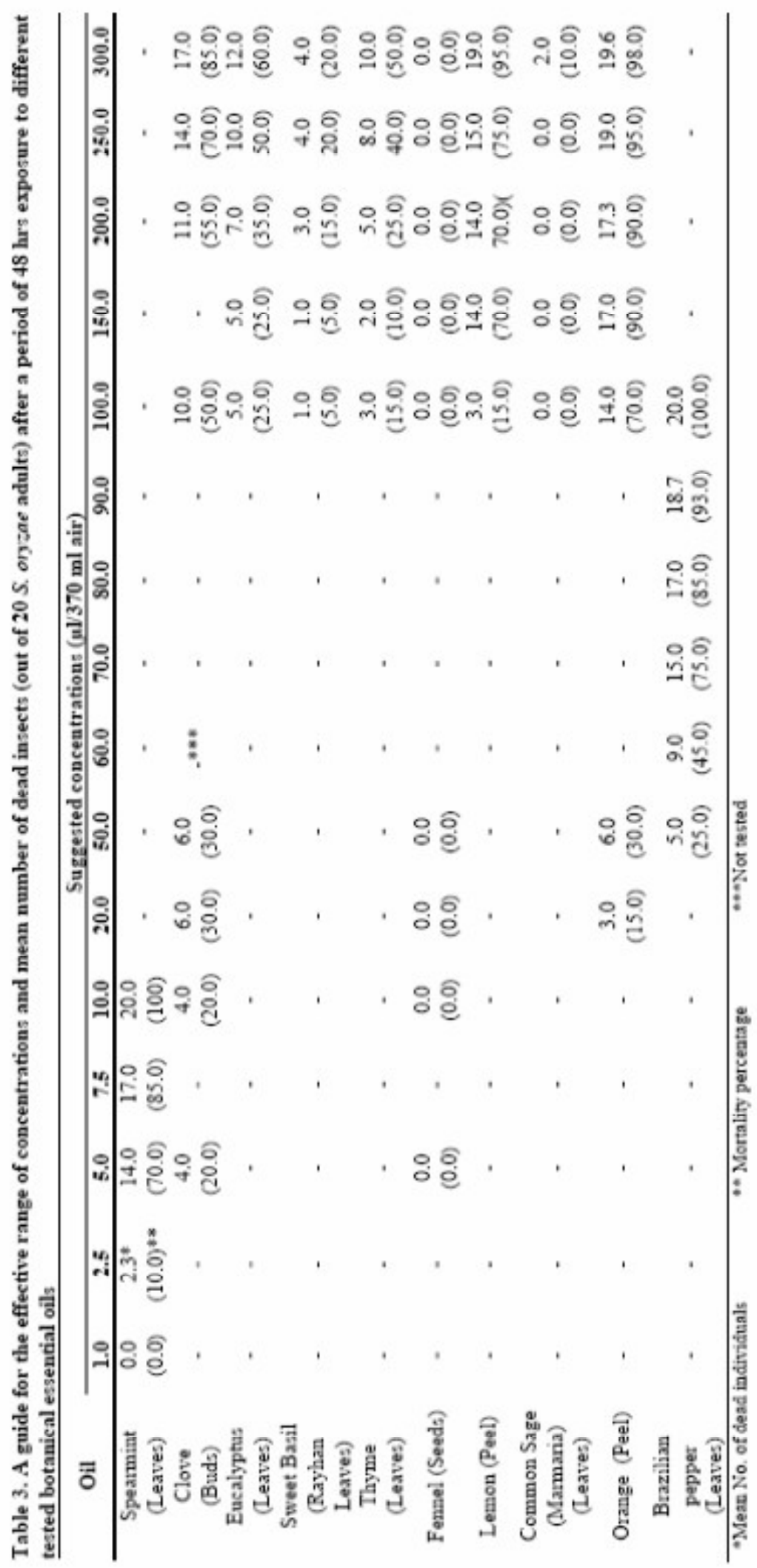




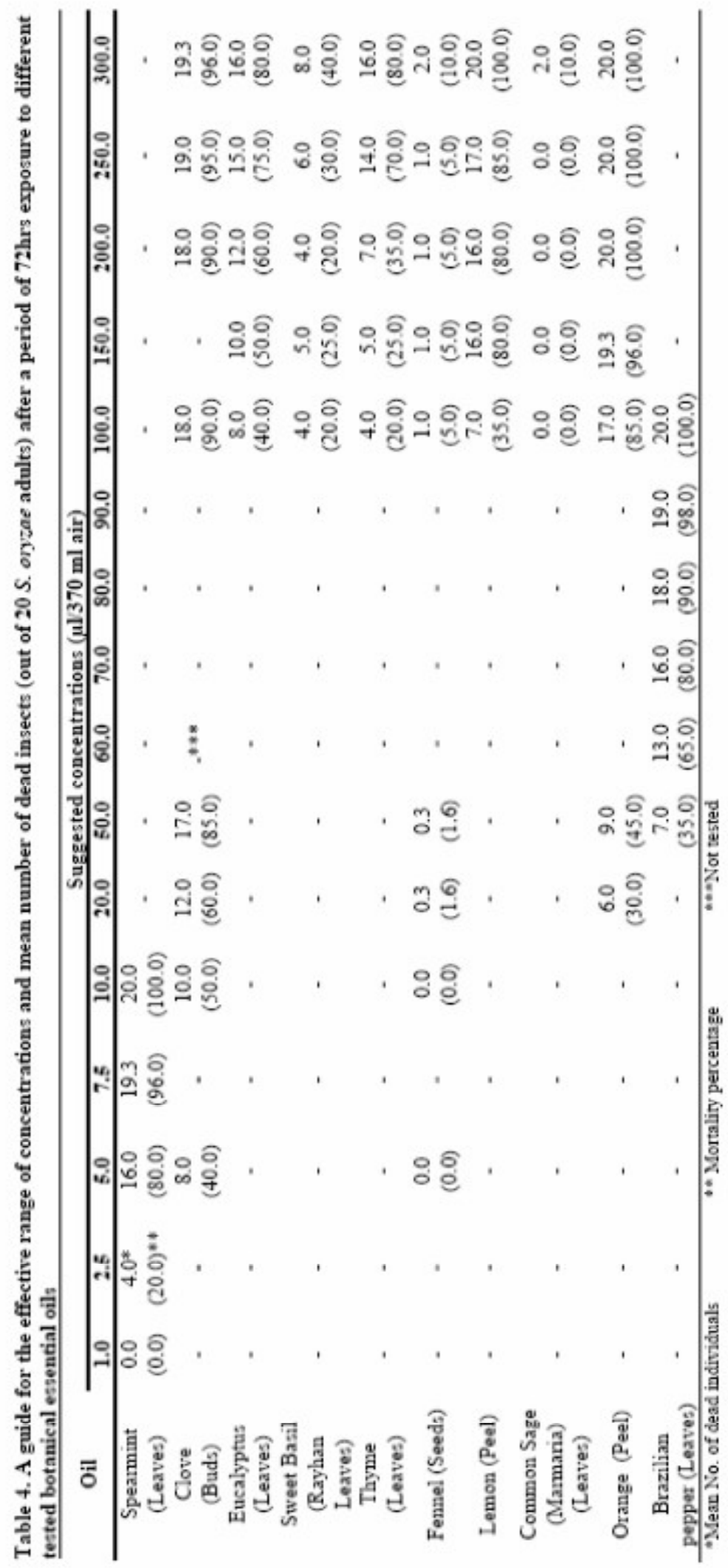




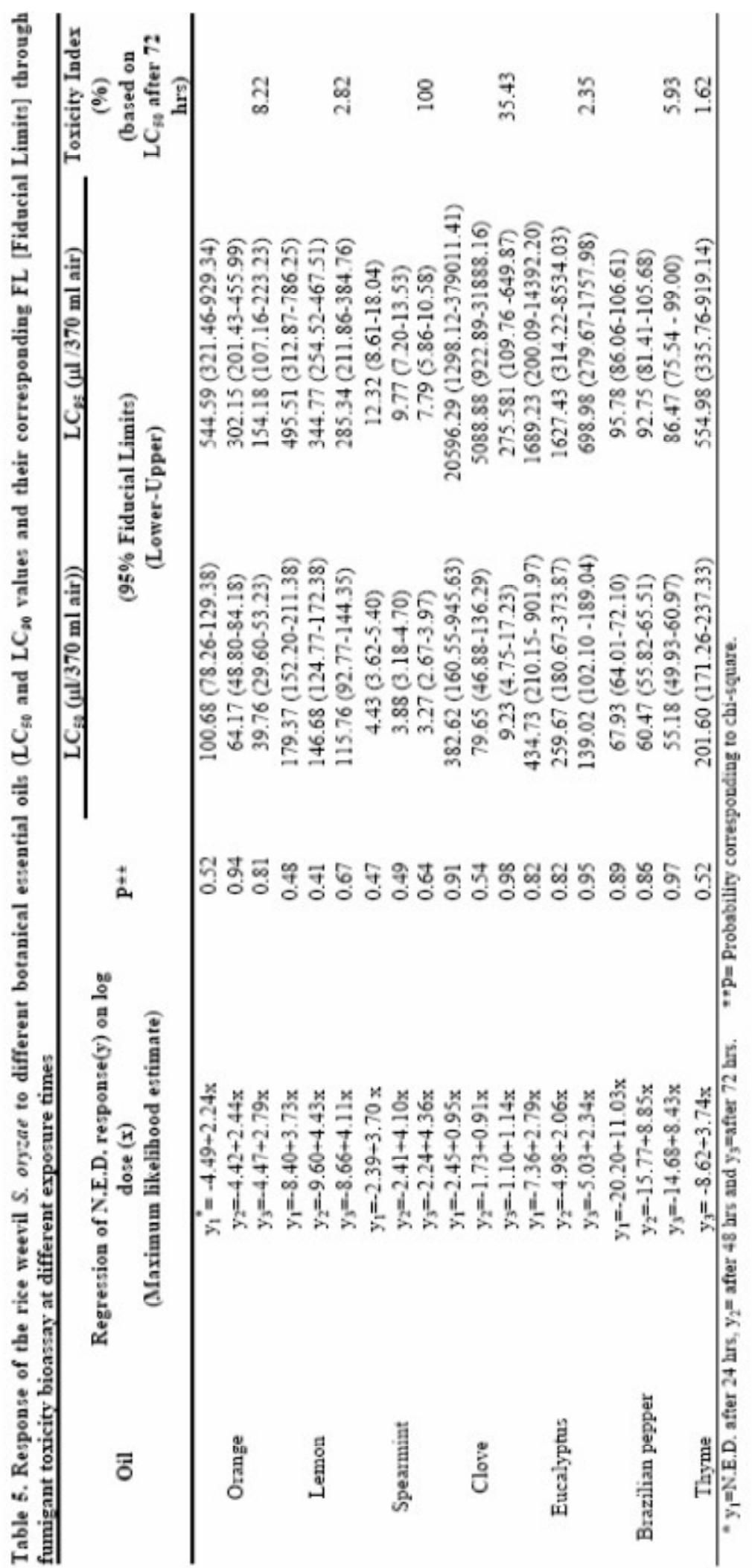




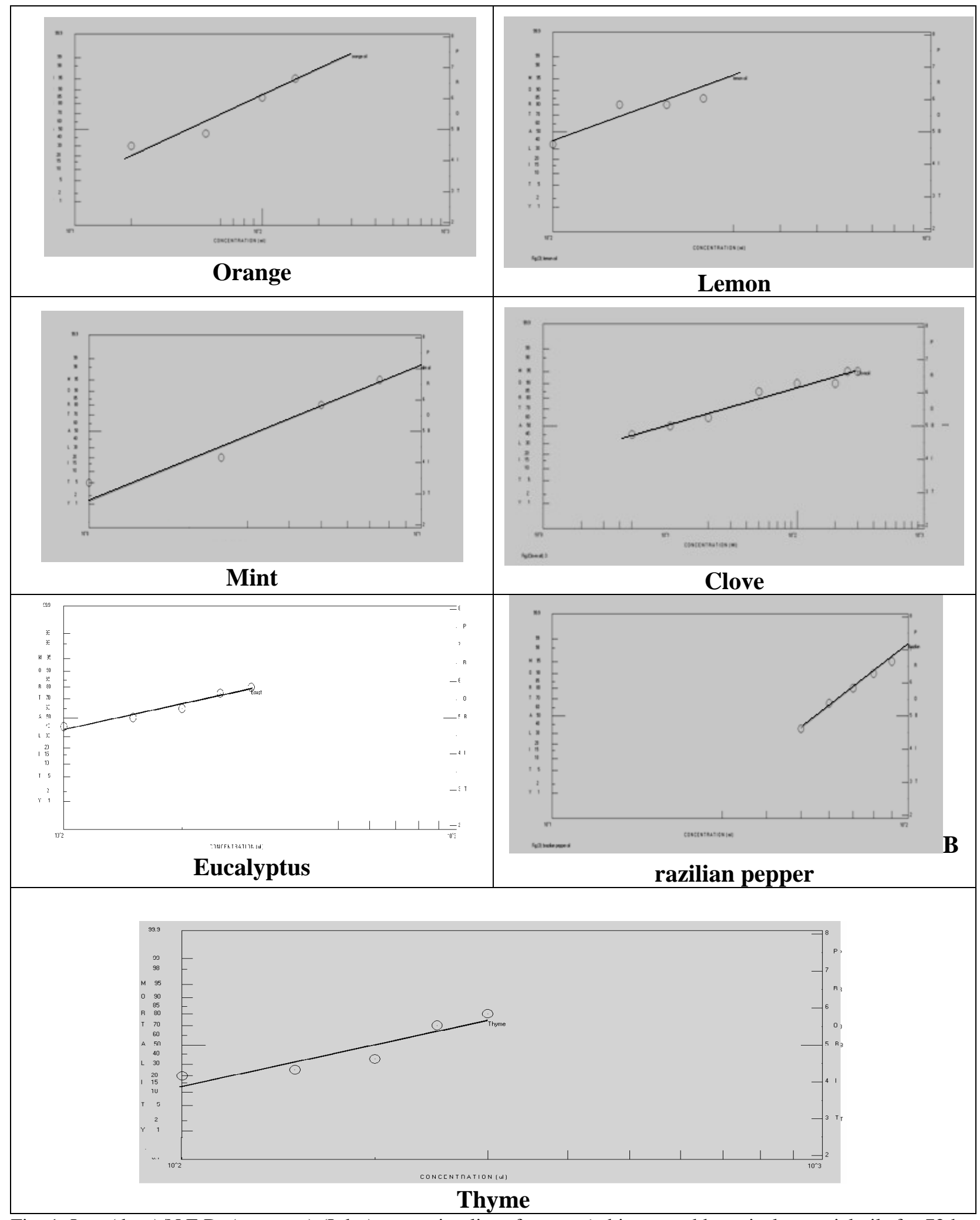

Fig. 1. Log (dose)/N.E.D. (response) (Ld-p) regression lines for certain bioassayed botanical essential oils for $72 \mathrm{hrs}$ against Sitophilus oryzae 
Moreover, the calculated values of the toxicity index proved that EO of spearmint was the most effective tested compound (100\%), followed by clove $(35.43 \%)$, orange $(8.22 \%)$ and Brazilian pepper EOs $(5.93 \%)$ (Table 5).

In this concept, these results could be attributed to the compounds presented in the essential oils of spearmint, clove, orange and Brazilian pepper, whereas the toxicity of spearmint is due to its biologically active major compounds that have been found in peppermint (menthol, isomenthone, limonene and 1,8cineole) (Snoussi et al., 2015). The Brazilian pepper leaves was found to contain up to $5 \%$ essential oil including biologically active triterpenes and sesquiterpenes. The essential oil present in the leaves, bark, and fruit of the Brazilian pepper tree is a rich source of chemicals (over 50 constituents identified thus far, including biologically active triterpenes and sesquiterpenes) (deNascimento et al., 2012).

Figure (1) is showing the log (dose)/N.E.D. (response) (Ld-p) regression lines for certain bioassayed botanical essential oils for $72 \mathrm{hrs}$ against Sitophilus oryzae. The presented results are in agreement with those of Derbalah and Ahmed (2011) who showed that the oil and powder of $M$. viridis were effective against $S$. oryzae with the respect to adults mortality. Relevant results have been described for Mentha species essential oils in controlling diverse pests of stored products. Benayad et al. (2012) evaluated the chemical composition and insecticidal effect of essential oils of $M$. suaveolens and $M$. pulegium against $S$. oryzae and $R$. dominica. The essential oils were very toxic for the two Coleopteran species within the first 24 hours, with $100 \%$ mortalities when concentrations of $50 \mu \mathrm{l}$ and $12 \mu \mathrm{l} /$ Petri dish of 9 $\mathrm{cm}$ diameter were used, respectively.

The toxic effects of essential oils involve many factors, among which are the entry points of toxins (inhaled, ingested or absorbed) and which may have contact, fumigation and phagoinhibitory effects (Regnault-Roger, 1997). The variation in toxicity was found to depend upon the type of the evaluated essential oils. The essential oils, especially those oils of spearmint and clove can be used as effective control agent for stored grain pests by fumigation. However botanical compounds have some limitations such as low bioavailability, high volatility and photodegradation that restrict their use in several occasions (Madhusudhanamurthya et al., 2013).

A number of investigations (Ho et al., 1997; Huang et al., 1998) have demonstrated contact, fumigant and antifeedant effects of a range of essential oil constituents (cinnamaldehyde, $\alpha$-pinene, anethole), as well as extracts of cloves (Syzygium aromaticum) and star anise (Illicium verum) against the red flour beetle (Tribolium castaneum) and the maize weevil (Sitophilus zeamais). Eugenol, the major constituent of oil of cloves and holy basil, Ocimum suave, was shown to be effective against $\mathbf{S}$. zeamais and $\mathbf{T}$. castaneum and another two additional coleopterans, S. granarius and Prostephanus truncatus (Obeng-Ofori and Reichmuth, 1997). Essential oils and their combinations were also useful as fumigants for the protection of stored rice against the rice weevil (Lee et al., 2001b).

Essential oils from different plant species possessed ovicidal, larvicidal and repellent effects against various insect species and are regarded as environmentally compatible pesticides (Isman, 2000; Cetin et al., 2004). This study has explored the potential for development of certain essential oils (spearmint, clove, orange and Brazilian pepper) especially from conifers to be effective, economically and environmentally friendly commercial insecticides for controlling the rice weevil Sitophilus oryzae.

\section{REFERENCES}

Abbott, W. S. 1925. A method of computing the effectiveness of insecticides. J. Econ. Entomol. 18: 265-267.

Abrha, L. H. and C. R. Unnithan.2014. Chemical composition and antibacterial activity of essential oil of Schinus molle. Unique J. Pharma. Biol.Sci.2.(1):9-12.

Agarwal, M., S. Walia, S. Dringra and B. P. S Khambay.2001. Insect growth inhibition, antifeedant and antifungical activity of compounds isolated/derived from Zingiber officinale Roscoe (ginger) rhizomes. Pest Manag. Sci. 57: 289-300.

Benayad, Nisrin, Weaam Ebrahim, A. Hakiki and Mahjouba Mosaddak. 2012. Chemical characterization and Insecticidal evaluation of the essential oil of Mentha suaveolens L. and Mentha pulegium L. growing in Morocco. St. Cerc. St. CICBIA, 13 (1): 27-32.

Bendaha, H., B. Bouchal, I. El Mounsi, A. Salhic, M. Berrabehd, M. El Bellaouib and M. Mimounia.2016. Chemical composition, antioxidant, antibacterial and antifungal activities of peel essential oils of citrus aurantium grown in Eastern Morocco. Der Pharmacia Lettre. 8.(4):239-245.

British Pharmacopoeia.1988. British pharmacopoeia, London: HMSO.2:137-138.

Calil, A. C. P. 1995. Efeito de doses de fosfina e per?odos de exposiç?o, na mortalidade de formas adultas e imaturas de Rhyzopertha dominica (Coleoptera: Bostrichidae), em trigo. Tese de Doutorado, Viçosa, Universidade Federal de Viçosa. 67 p.

Camara, C. A. G., Y. Akhtar, M. B. Isman and C. R. Seffrin.2015. Repellent activity of essential oils from two 
species of Citrus against Tetranychus urticae in the laboratory and greenhouse. Crop Protect.74:110-115.

Cardoso, M. G., A. Y. K. V. Shan, J. E. B. P. Pinto, N. Delu Filho and S. K. V. Bertolucci.2001. Metab?litos secund?rios vegetais: vis?o geral qu?mica e medicinal. Lavras, UFLA. 81 p.

Cases, A., B. Pérez, P. Navarrete, E. Mora, B. Pe?a, A. Peluzzo, R. Calvo, D. S?nchez de Ron and F. Varela.2009. Variability in the chemical composition of wild Thymus vulgaris L. Acta Hort. (ISHS). 826:159-166.

Cetin, H., F. Erler and A. Yanikoglu.2004. Larvicidal activity of a botanical natural product, AkseBio2, against Culex pipiens. Fitoterapia. 75. (7/8): $724-728$.

Dambolena, J. S., Maria P. Zunino, A. G. L?pez, H. R. Rubinstein, J. A. Zygadlo, J. W. Mwangi, G. N. Thoithi, I. O. Kibwage, J. M. Mwalukumbi, and S. T. Kariukie. 2010. Essential oils composition of Ocimum basilicum L. and Ocimum gratissimum L. from Kenya and their inhibitory effects on growth and fumonisin production by Fusarium verticillioides. Innov. Food Sci. Emerg. Technol. 11(2):410-414.

deNascimento, A. F., D. A. C. Cag, M. M. de. Moraes and C. S. Ramos .2012. Essential oil composition and acaricidal activity of Schinus terebinthifolius from Atlantic Forest of Pernambuco, Brazil against the mite Tetranychus urticae. Nat Prod Commun. 7(1): 129-132.

Derbalah, A. S. and Sahar I. Ahmed.2011. Oil and powder of spearmint as an alternative to Sitophilus oryzae chemical control of wheat grains. J. Plant Protec. Res. 51(2):145150.

Dubey, N. K., A. Kumar, P. Singh and R. Shukla .2010. Exploitation of natural compounds in eco-friendly management of plant pests (Chapter 14). In: U. Recent Developments in Management of Plant Diseases, Gisi et al. (eds.). Springer Science + Business Media B.V. 181198.

Feng, W. and X. Zheng .2007. Essential oil to control Alternaria alternata in vitro and in vivo. Food Control. 18:1126-1130.

Finney, D. J. 1971. Probit Analysis, $3^{\text {rd }}$ Edition, Cambridge University Press, Cambridge, U.K. pp 333.

Franz, A. R., N. Knaak and Lidia Mariana Fiuza.2011. Toxic effects of essential plant oils in adult Sitophilus oryzae (Linnaeus) (Coleoptera, Curculionidae). Rev. Bras. Entomol. 55 (1):116-120.

Frizzo, Caren D., Ana C. Santos, Natalia Paroul, Luciana A. Serafini, E. Dellacassa, D. Lorenzo and P. Moyna.2000. Essential oils of camphor tree (Cinnamomum camphora Nees \& Eberm) cultivated in Southern Brazil. Braz. Arch. Biol. Technol. 43 (3):1-4.

He, W. and B. Huang.2011. A review of chemistry and bioactivities of a medicinal spice: Foeniculum vulgare. J. Med. Plants Res. 5(16):3595-3600.
Ho. S. H., Y. Ma and Y. Huang.1997. Anethole, a potential insecticide from Illicium verum Hook F., against two stored product insects. Int. Pest Control. 39:50-51.

Huang, Y., S. K. Hee and S. H. Ho.1998. Antifeedant and growth inhibitory effects of a-pinene on the stored-product insects, Tribolium castaneum (Herbst) and Sitophilus zeamais Motsch. Int. Pest Control.40:18-20.

Isman, M. B. 2000. Plant essential oils for pest and disease management. Crop Protection. 19 (8/10): 603 - 608.

Isman, M. B. 2006. Botanical insecticides, deterrents, and repellents in modern agriculture and an increasingly regulated world. Annu Rev. Entomol. 51:45-66.

Joshi, R. K. 2013. Chemical composition, in vitro antimicrobial and antioxidant activities of the essential oils of Ocimum gratissimum, $O$. sanctum and their major constituents. Indian J. Pharmacol. Sci. 2013. 75:457-462.

Kim, D. H. and Y. J. Ahn.2001. Contact and fumigant activities of constituents of $F$. vulgare fruit against three coleopteran stored-product insects. Pest Manag. Sci. 57: 301-306.

Lazzari, F. A. and S. M. N. Lazzari.2002. Colheita, recebimento, secagem e armazenamento de milho. Apucarana, ABIMILHO.22 p.

Lee, B., W. Choi, S. Lee and B. Park .2001a. Fumigant toxicity of essential oils and their constituent towards the rice weevil, Sitophilus oryzae (L.). Crop Prot.20:317-320.

Lee, C. H., B. K. Sung and H. S. Lee .2006. Acaricidal activity of fennel seed oils and their main components against Tyrophagus putrescentiae, a stored-food mite. J. Stored Prod. Res. 42(1): 8-14.

Lee, S. E., B. H. Lee, W. S. Choi, B. S. Park, J. G. Kim and B. C. Campbell.2001b. Fumigant toxicity of volatile natural products from Korean spices and medicinal plants towards the rice weevil, Sitophilus oryzae (L). Pest Manag. Sci. 57:548-553.

Liu, C. H., A. K. Mishra, R. X. Tan, C. Tang, H. Yang and Y. F. Shen .2006. Repellent and insecticidal activities of essential oils from Artemisia princeps and Cinnamomum camphora and their effect on seed germination of wheat and broad bean. Bioresour. Technol,.97:1969-1973.

Madhusudhanamurthya, J., Rania P. I. Usha and K. R. S. Sambasiva Raob.2013. Organic-inorganic Hybrids of Nano Silica and Certain Botanical Compounds for their Improved Bioactivity Against Agricultural Pests. Cur. Trends Biotechnol. Pharm. 7 (2): 615-624.

Mimica-Dukić, N., S. Kujundžić, M. Soković and M. Couladis .2003.. Essential oils composition and antifungal activity of $F$. vulgare Mill. obtained by different distillation conditions. Phytother. Res. 17(4): 368-371.

Moreira, R. G. 1993. Aeraç?o de gr?os usando ar natural e frio.p. 177-196. In: International Symposium on Grains Conservation. Proceedings, Canela, 1076 p. 
Nassar, M. I., A. H. Gaara1, A. H. El-Ghorab, A. H. Farrag, H. Shen, E. Huq and T. J. Mabry .2007. Chemical constituents of clove (Syzygium aromaticum, Fam. Myrtaceae) and their antioxidant activity. Rev. Latinoamer. Qu?m., 35(3):47-57.

Obeng-Ofori, D. and C. Reichmuth (1997). Bioactivity of eugenol, a major component of essential oil of Ocimum suave (Wild.) against four species of stored--product Coleoptera. Int. J. Pest Manag., 43:89--94.

Pacheco, I. A. and D. C. Paula.1995. Insetos de gr?os armazenados - identificaç?o e Biologia. Campinas, Fundaç?o Cargill. 228 p.

Pereira, P. R. V. S., R. S. Furiatti, F. A. Lazzari and A. R. Pinto J?nior. .1997. Evaluation of insecticides in the control of Sitophilus oryzae (L.) (Coleoptera: Curculionidae) and Rhyzopertha dominica (Fab.) (Coleoptera: Bostrichidae) in shelled corn. Anais da Sociedade Entomol?gica do Brasil.26: 411-416.

Porte, A., R. L. O. Godoy and Maia L. H. Porte.2013. Chemical composition of sage (Salvia officinalis L.) essential oil from the Rio de Janeiro State (Brazil). Rev. Bras. Pl. Med. Campinas.15(3):438-441. 2013.

Prates, H. T. and J. P. Santos.2002. ? leos essenciais no controle de pragas de gr?os armazenados, p. 443-461. In: Armazenagem de gr?os. Lorini, I.; L. H. Miike \& V. M. Scussel (Eds.). Ed Campinas: IBG. 1000 p.

Rajendran, S. and V. Sriranjini.2008. Plant products as fumigants for stored-product insect control. J. Stored Prod. Res. 44:126-135.

Regnault-Roger, C. 1997. The potential of botanical essential oils for insect pest control. Integrated Pest Management Rev. 2: 25-34.

Regnault-Roger, C., A. Hamraoui, M. Holeman, E. Theron and R. Pinel (1993). Insecticidal effect of essential oils from Mediterranean plants upon Acanthoscelides obtecus
Say (Coleoptera: Bruchidae), a pest of kidney bean (Phaseolus vulgaris L.). J. Chem. Ecol., 19:1233-1244.

Sartori, M. R., I. A. Pacheco, M. Iaderosa and R. W. D. Taylor.1990. Ocorrência e especificidade de resistência ao inseticida malation em insetos-pragas de gr?os armazenados no Estado de S?o Paulo. Coletânea do ITAL. 20: 94-209.

Smiderle, O. 2007. Manejo integrado de pragas de gr?os armazenados: identificaç?o e controle. Available from: http://www.infobibos.com/Artigos/2007?2/PragaGraos/ind ex.htm .

Snoussi, M., Emira Noumi, Najla Trabelsi, G. Flamini, A. Papetti and V. De Feo.2015. Mentha spicata essential oil: Chemical composition, antioxidant and antibacterial activities against planktonic and biofilm cultures of Vibrio spp. strains. Molecules. 20(8):14402-14424.

Sun, Y. P. 1950. Toxicity Index-An improved method of comparing the relative toxicity of insecticides. $J$. Econ. Entomol.43(1): 45-53.

Tayoub, G., M. Alorfi and Hala Ismail.2016. Fumigant toxicities of essential oils and two monoterpenes against potato tuber moth (Phthorimaea operculella Zeller). Botan. Med. Res. 62(4): 82-96.

Traboulsi, A. F., S. El-Haj, M. Tueni, K. Taoubi, N. A. Nader and A. Mrad.2005. Repellency and toxicity of aromatic plant extracts against the mosquito Culex pipiens molestus (Diptera: Culicidae). Pest Manag. Sci. 61(6): 597-604.

Verzera, A., A. Trozzi, G. Dugo, D. Bella and A. Cotroneo.2004. Biological lemon and sweet orange essential oil composition. Flavour Fragr. J. 19:544-548.

Yazdgerdian, A. R., Yasmin Akhtar, Murray B. Isman.2015. Insecticidal effects of essential oils against woolly beech aphid, Phyllaphis fagi (Hemiptera: Aphididae) and rice weevil, Sitophilus oryzae (Coleoptera: Curculionidae). J. Entomol. Zool. Studies. 3.(3):265-271. 


\section{الملخص العربي \\ الزيوت النباتية كبدائل آمنة بيئياً لمكافحة سوسة الأرز

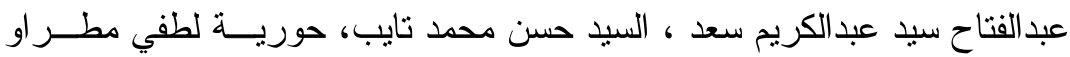

تعتبر سوسة الأرز من الحشرات الهامة التي تصيب وأظهرت النتائج أن الزيت المستخرج من النعناع البلدي

الحبوب المخزونة وبالذات القمح والأرز والذرة. وقد تم كان له سمية عالية و أعطي أقل قيم تركيزات قاتلة لنسبة

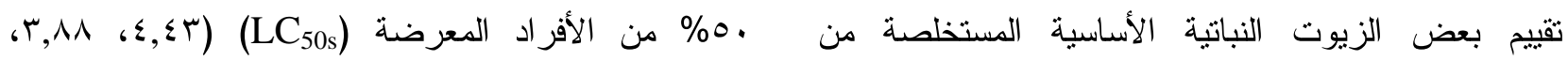

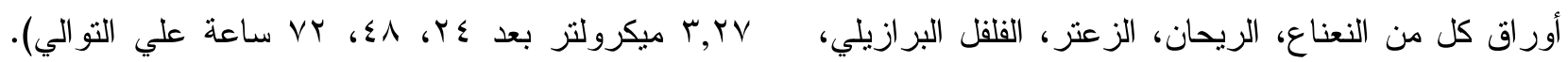

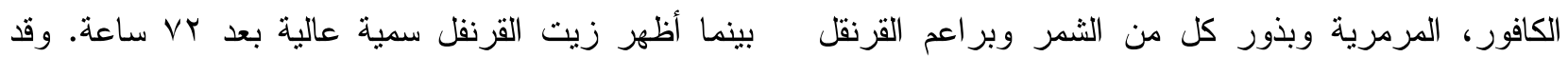

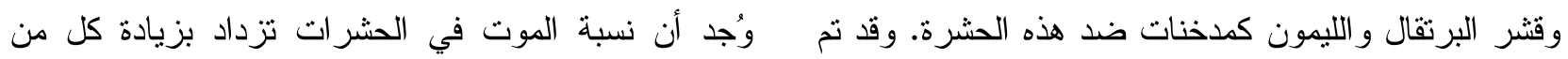

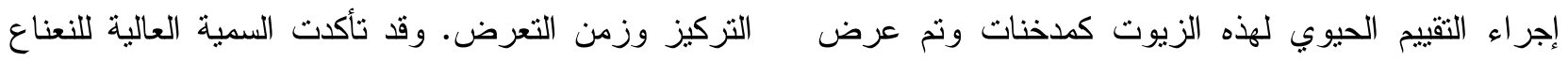

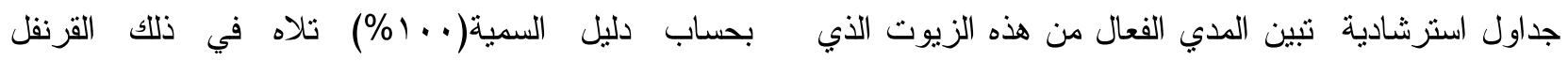

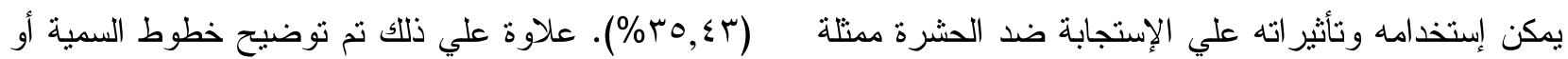

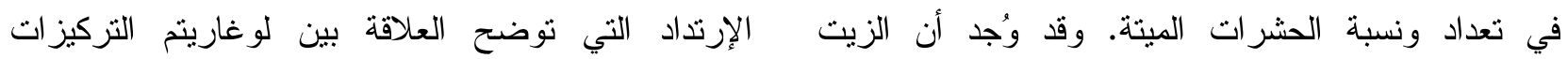

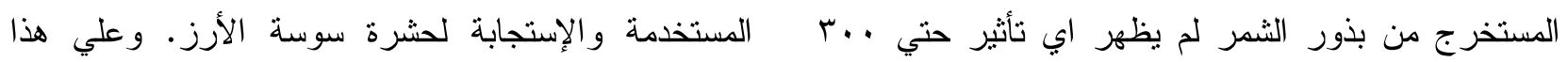

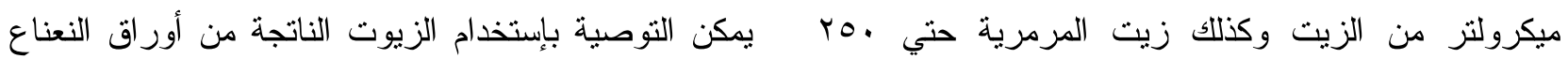

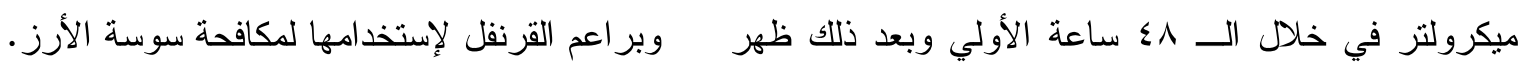
لهما تأثير طفيف وضعيف (بعد في هاعة). 